\author{
香川 靖雄
}

\title{
Prevention of lifestyle-related diseases by chronological nutrition
}

\author{
Yasuo Kagawa

\begin{abstract}
女子栄養大学医化学研究室， ₹350-0288 埼玉県坂戸市千代田3-9-21 (Department of Medical Chemistry, Kagawa Nutrition University, 3-9-21 Chiyoda, Sakado, Saitama 350-0288, Japan)
\end{abstract}

Received / Accepted: April 16, 2014

\begin{abstract}
Chronological nutrition is based on biological clocks that include clock genes and telomeres. Clock genes predict the day/night cycle to regulate both physical and mental activity in best condition, and prevent lifestyle-related diseases. Telomeres, the repeated series of DNA sequences that cap the ends of chromosomes, become shorter during cell division, thus determine lifespan of the individuals and organs. Even when dietary intake and exercise are adequate, disturbance of diurnal rhythm results in hypertension and hyperglycemia. Human activity is driven by NADH and ATP produced from nutrients, and the resulting NAD and AMP prevent telomere shortening by activating enzymes called SIRT1 and AMPK, respectively. Both enzymes collaborate in activating the master regulator PGC- $1 \alpha$ that prevents oxidative stress and obesity. Physical activity increases PGC- $1 \alpha$ and releases a hormone irisin from muscle that also prevents obesity. The dietary habit conforming good chronological nutrition are as follows: take nutritionally balanced breakfast every morning, distribute energy intake in the ratio breakfast: lunch: dinner $=3: 3: 4$, and avoid dinner later than 21 o'clock or take earlier light dinner. Slow feeding and the intake of vegetables before carbohydrate are recommended to prevent rapid blood sugar increase. Regular 7 hour sleep is essential for the removal of metabolic wastes by "brain glymph system" to prevent dementia. The homeostatic and hedonic feeding and daily activity are controlled by human brain. Thus, lifestyle-related diseases will be prevented by moderation following the principles of chronological nutrition, irrespective of risk gene polymorphism.
\end{abstract}

Jpn J Phys Fitness Sports Med, 63(3): 293-304 (2014)

Keywords : clock gene, telomere, circadian rhythm, diabetes

\section{緒言}

体力や学力を増進し, 生活習慣病を予防するとして期 待されているのが時間栄養学である。生活習慣病は時間 経過に伴う生命現象であることは自明であるが，それを 支配している時計遺伝子とテロメアの関連から生活習慣 病を解析した論文 ${ }^{1,2)}$ は少ない. その理由は人体の時計遺 伝子の分子機構が知られたのは今世紀に入ってからで, テロメア研究にノーベル医学生理学賞が授与されたのも 2009年のことだからである。あらゆる生物は微生物から 植物, 動物まで, 昼夜を予測して, 事前に体制を準備す る時計遺伝子を持っている ${ }^{1,2)}$. 例えば朝顔は暗所でも朝 に咲くのは時計遺伝子が開花を決めているからである。 人体では午前 4 時には活動を高める副腎皮質ホルモンの 分泌が始まり, 同時に睡眠ホルモンのメラトニンは減る. このように時計遺伝子には未来予測能と機能分業能があ り，早朝には活動条件を整えるのと同時に休息の代謝は
抑制する。

ヒトでは主時計遺伝子は脳の視交叉上核にあり, 朝日 を網膜で感受して，時計遺伝子の位相を朝に合わせる (Fig. 1). 末梢時計遺伝子は消化器を始め全身の細胞に あり，朝食摂取によって位相を整える，両時計遺伝子が 同調して, 神経, 内分泌の各系の円滑な活動で, 心身を 活性化し，ストレスにも耐える1,2)。交代勤務や時計遺伝 子の変異によって日周リズム変調が起こると高血圧, 高 血糖を誘発して, 循環器疾患, 糖尿病のリスクが高まる (Fig. 1中下). 時間栄養学の長期の指標はテロメア長で ある ${ }^{1,2)}$. テロメア長は細胞分裂毎に短縮するため, ヒト 体細胞には50回の分裂寿命しかない. 出生時に 1 万塩基 あったテロメア長が年間平均 50 塩基ずつ短縮して行き, 約 5 千塩基以下では生存できない。寿命と関係が深い内 皮細胞はFig. 1 中央に示す高血圧, 高血糖, 高脂血, 活 性酸素によって死滅し, それを代償的に修復するため細 胞分裂が促進されて, やがて多くの内皮細胞のテロメア 
長が分裂寿命に達して動脈硬化が進み，脳卒中，心筋梗 塞が発症する。中高年期に開始した生活習慣病の薬物治 療でたとえ血圧, 血糖等の諸指標を正常化しても, テロ メア長は短縮しており，若年期から節制を行った場合の 脳卒中，心筋梗塞のリスクの低さを達成することはでき ない (レガシー効果)。これに対して飽食や運動不足は 肥満を招き, 糖尿病や循環器疾患を経て, 最終的にはテ ロメア長の短縮によって健康寿命を短縮させる（Fig. 1 右下 $)^{1)}$.

\section{生活習慣病と生物時計}

生活習慣病予防のために最適の栄養摂取量と運動を揃 えても，日周リズムを乱すだけで，高血圧，肥満，高血 糖等を起こすことが人体試験で確認されている ${ }^{1,3)}$. 寿 命と睡眠時間の関係を百十万人で調査すると, 睡眠時間 が平均 7 時間の人は最も死亡率が低く, 8 . 5 時間以上また は4.5時間未満の睡眠時間では死亡のリスクが15\%高ま る $(\text { Fig. 2 })^{4}$. この睡眠時間と寿命の関倸 ${ }^{4}$ をテロメア長 で実測すると，睡眠の質が悪いほどテロメア長が短縮す るのである ${ }^{5)}$ ，テロメアが短縮する理由は生活習慣病に よる細胞死の代償的細胞分裂と, 活性酸素によるテロメ アの破壊である。睡眠時間が 7 時間よりも長くても短く てもBMIが増加し, 生活習慣病の発生頻度が増し, 死亡 率が高まるのである4)。遺伝要因による日周リズムの乱 れによって, 高血圧と 2 型糖尿病が発症することは確認 されており，例えばBmal1変異の厐大な HapMap Projectのデータから結論された ${ }^{6)}$ 。 とくに睡眠時間の糖尿 病, 高血圧, 肥満 (BMI) などの生活習慣病の発症頻度 は睡眠時間 7 時間を最小として，Fig. 3のように，睡眠 不足でも，睡眠過多でも増加するのである77)。これに対 して，食欲と大きな関連のあるレプチンとグレリンの分 泌量は反対の方向に増減する (Fig. 3)。レプチンは脂肪 組織から分泌されて, 視床下部に作用して食欲抑制をす るので睡眠不足で食欲を充進させ肥満となるが，睡眠過 多では活動のエネルギー自体が少ないのでやはり肥満, 糖尿病のリスクが増す。グレリンは胃から分泌され，視 床下部に作用して食欲圥進作用を持つため, 睡眠不足は 肥満の一因となる。睡眠過多が活動減少で肥満となるの は理解できるが, 睡眠不足による肥満, 糖尿病の発生機 構はFig. 4 に要約されるように複雑である ${ }^{8)}$. 代謝の中 心である視床下部の変調, 脳糖代謝減少, 下垂体からの 成長ホルモン増加, 副腎からのコルチゾール分泌増加が 伴う。一方, 交感神経の緊張は代謝を促進はするが, 血 圧が上昇し, 循環器疾患の誘因となる。環境要因による 日周リズムの乱れの例としてシフトワーカーの高血圧, 2 型糖尿病, 癌の多発, 生活習慣病の進行も良く知られ ている ${ }^{1)}$. 生活習慣病予防に適した栄養, 運動をしても, 1 日 4 時間の日周リズム延長を 4 週間続けただけで，コ
ルチゾール周期の乱れ等を伴って肥満，高血圧，高血糖 のいずれもが有意 $(p<0.001)$ に発症し, 前糖尿病状態が 起こることが厳密な人体試験で確立された ${ }^{3)}$. Fig. 2, 3 のように, 睡眠覚醒，それに伴う栄養という毎日の時計 遺伝子の働きが80年近い生活習慣病の過程に Fig. 4の機 構8)を通して影響していることは時間栄養学が生活習慣 病予防の重要な要因であることを示している。

\section{時計遺伝子の機能と分子機構（略号は Fig.の説明参照）}

Fig. 1に示すように, 脳の視交叉上核に主時計遺伝子 があって約25時間の概日リズムを自律的に作る ${ }^{1,2)}$ 。朝 日は網膜の神経節細胞のメラノプシンに感受されて網膜 視床下部路から視交叉上核の主時計遺伝子に伝えられ て, 時計の自律的な 25 時間周期の概日リズムを 24 時間 の日周リズムにリセットして心身活動を始動する。この リセットは季節による日の出時刻の変動に体調を合わせ るためである。時計遺伝子は夕刻を予測して松果体のメ ラトニンを分泌させ睡眠を促す. Fig. 1下に示すように, 体内の各臟器には末梢時計遺伝子があり, 栄養バランス のとれた朝食でリセットされる。末梢時計遺伝子は臓器 を取り出しても数日間は独自のリズムを持つが，長期に は主時計遺伝子の影響下ある ${ }^{1,2)}$

概日リズムは時計遺伝子の転写と翻訳の負のフィード バックループで自動的に作られる。明確に説明するた めに，本総説では中核となるフィードバックループだ けを簡潔に述べる（Fig. 5) $)^{1,2)}$ ，転写制御因子のCLOCK とBMAL1は結合して 1 個の異型 2 量体 (CLOCK)

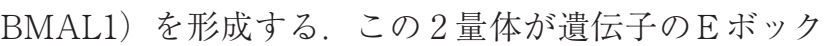
スという塩基配列に結合して, Per とCryという遺伝子 の転写を活性化する。こうして合成されたPERと CRY という蛋白質がPER/CRY複合体（抑制因子）となって, 自身の遺伝子の転写を促進するCLOCK/BMAL1の活性 を抑制する (Fig. 5 上右)。この結果 PER/CRY複合体が 減少し, PerとCry遺伝子の転写が再開される。この転 写活性化因子と転写抑制因子の交互の活動に時間差があ るために，振動が㧍こるのである (Fig. 5 上左)。ヒト のPER1〜PER3（マウスのPer1〜Per3）などの種特異 的な亜種がある。その上に，蛋白質リン酸化酵素はじめ 数十の関連蛋白質の候補遺伝子が概日リズム遺伝子の ネットワークに関与する ${ }^{1)}$. 重要な点は数百の遺伝子に も E-ボックスがあって周期的に代謝を変動させるので, その全てを時計制御遺伝子 (CCGs) と呼び, 全転写産物 の約10\%を産生して心身活動のリズムを作る (Fig. 5右). この日周リズムが乱れた場合の時計遺伝子の変調を筆 者等の食事時刻を移動させるマウスの実験でFig. 6 に示 す. 8 週間昼の給餌を続けてから, 臓器の末梢時計遺伝 子の発現で合成されたPerやBmall のRNAを逆転写酵 素でDNAに変換して定量する。マウスは夜行性である 


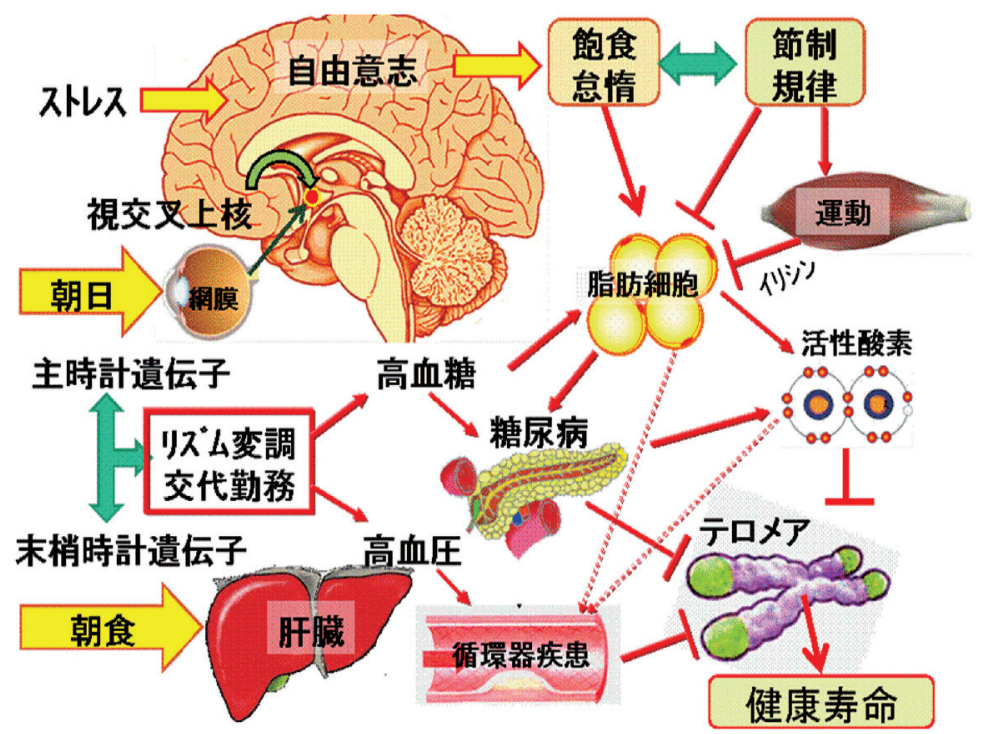

Fig. 1 Central roles played by the brain in controlling clock genes and telomere.

Environmental signals (yellow arrows), including stress, light, and breakfast, are received and processed by the cortex, SCN, and liver, respectively. Disturbed rhythm, such as shift work, causes hypertension and hyperglycemia. Based on the circadian rhythm of the master and peripheral clocks, voluntary will triggers a hedonic or moderate lifestyle. Regular life and exercise prevent obesity-related cardiovascular diseases and type 2 diabetes. The telomere length is shortened by ROS and cell proliferation to compensate cells lost to these diseases.

Abbreviations: ROS, reactive oxygen species; SCN, suprachiasmatic nucleus.

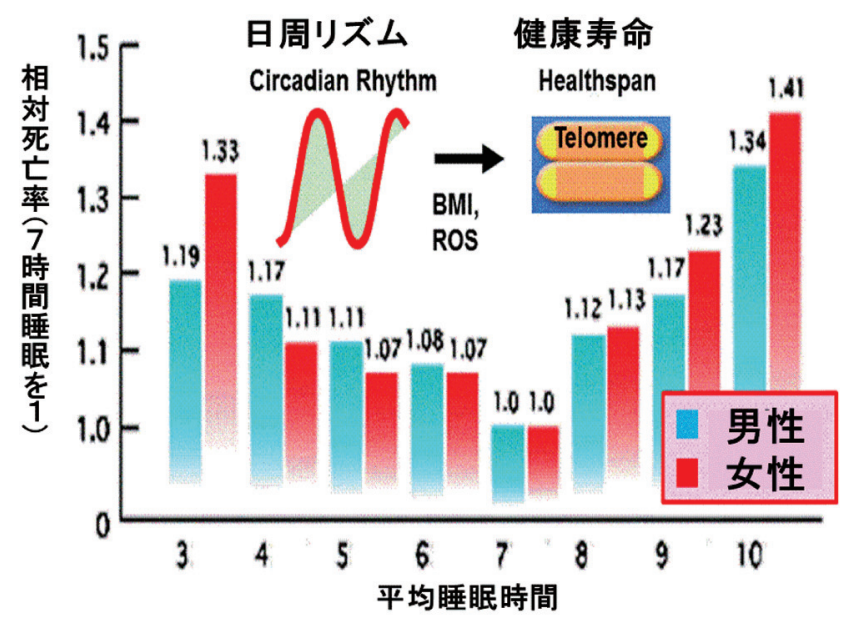

Fig. 2 Mortality hazard ratios for various reported sleep durations for men and women.

Data collected from 636,095 men and 480,841 women in the Cancer Prevention Study II (1982-1988). Both men and women with a usual sleep duration of $7 \mathrm{~h}$ had the best survival. Participants reporting sleep durations $\leq 6 \mathrm{~h}$ and $\geq 8 \mathrm{~h}$ had significantly increased mortality hazard. The daily activity of clock gene is finally accumulated in telomere and healthspan. Adapted from Ref. 4.

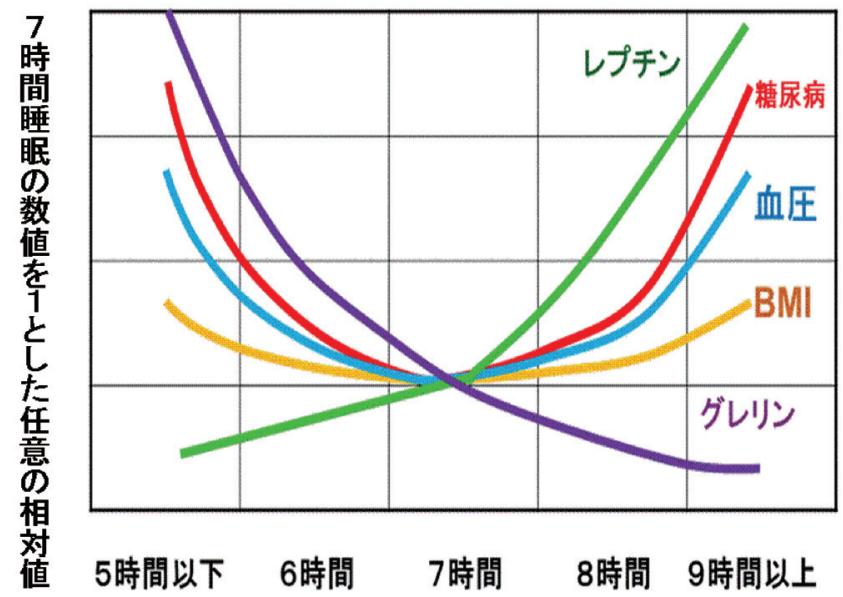

Fig. 3 Relationship between sleep duration and prevalence of hypertension, type 2 diabetes and obesity (BMI).

Data for hypertension are from the Sleep Heart Health Study. Usual sleep times $\leq 6 \mathrm{~h}$ or $\geq 9 \mathrm{~h} /$ night were associated with an increased prevalence of type 2 diabetes and impaired glucose tolerance. After adjustment for age and sex, those sleeping more and less than $7.7 \mathrm{~h} /$ night had an increased BMI with curvilinear relationship. Serum leptin and ghrelin concentrations increase and decrease, respectively depending on the sleep duration. Increased BMI and reactive oxygen species produced by obesity and diabetes shorten both telomere length and healthspan. Data are adapted from Ref. 7.

るのである $(\text { Fig. 8 })^{9)}$. Fig. 8に示す遺伝子の中で影響 を受けた時計遺伝子群はPER1, PER2, PER3, CRY, $C L O C K$ 等であった ${ }^{9)}$. また, 睡眠不足時にのみ増加した リズムで発現する遺伝子群は主に蛋白質合成に関与する 遺伝子であった。このように環境の影響でリズムが変調 する場合の他にCLOCK (Fig. 6) やBMAL1等の変異に よるリズムの変調もある ${ }^{6)} . B M A L 1$ が欠損すると寿命 が短縮し，様々な疾患が発生するのである ${ }^{10)}$ 。これらの 時計遺伝子の変異によって, CCGsの発現も変動を受け, 

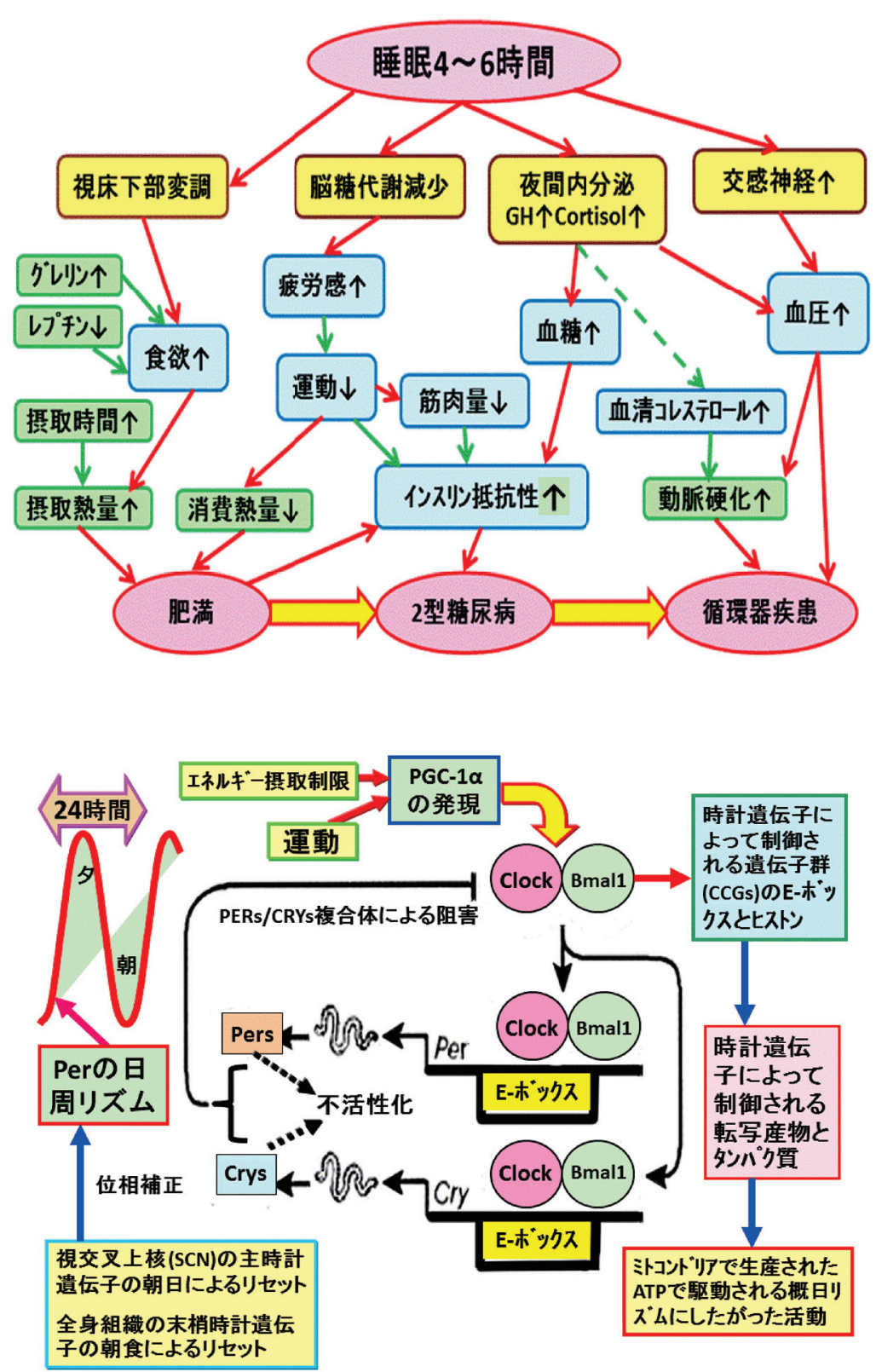

Fig. 4 Partial sleep deprivation and disturbance of energy balance causes lifestyle related diseases including obesity, type 2 diabetes and cardiovascular diseases. Adapted from Ref. 8.

Fig. 5 A simplified negative feedback loop of the mechanism responsible for human circadian rhythm generation.

The process begins when Clock/Bmall heterodimers drive the transcription of Per and Cry genes and translate the mRNA into Per and Cry proteins, respectively. When levels of Per and Cry proteins reach a threshold, they form heterodimers and inhibit Clock/Bmall-mediated transcription of their own genes. The resulting decrease in Per/Cry resumes their own transcription. This feedback loop takes about $25 \mathrm{~h}$, thereby resulting in a free-run circadian rhythm, which is converted into a 24-h diurnal rhythm by resetting the clock genes with morning light and breakfast. Abbreviations: Bmall, brain and muscle ARNT-like protein 1; Clock, circadian locomotor output cycles kaput; $\mathrm{CR}$, caloric restriction; Cry/Crys, cryptochrome; E-box, nucleotide sequence CACGTG in the regulatory region of a gene; $\mathrm{PGC}-1 \alpha$, peroxisome proliferator-activated receptor coactivator $\alpha$; Per/ Pers, period. (Ref. 1)
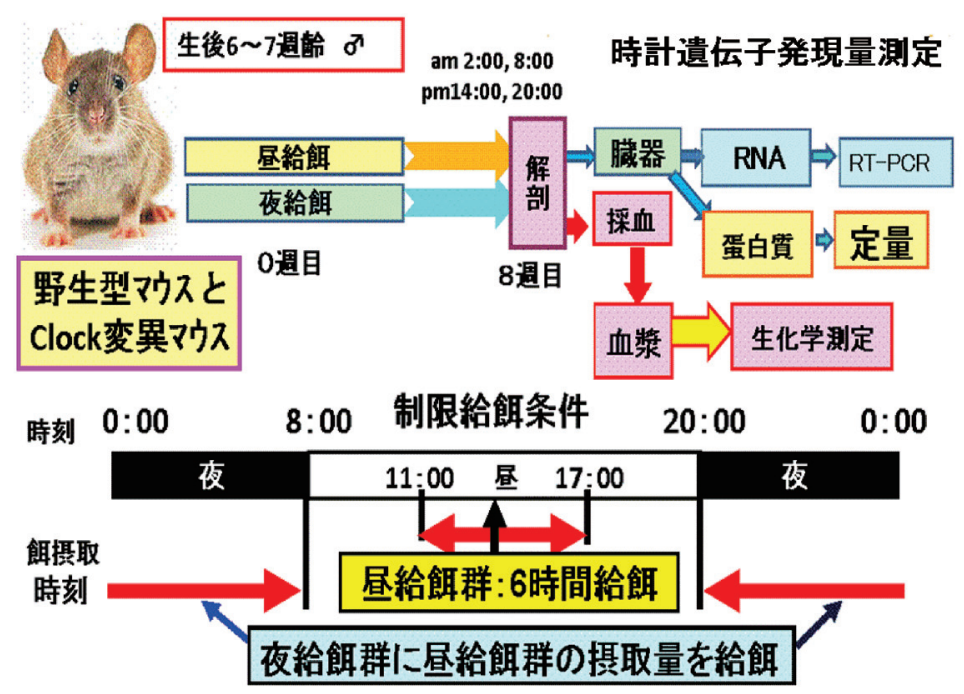

Fig. 6 Change in meal timing of mice affects the clock gene activity. (Hiraishi, M., Kagawa, Y. and Horie S. 132th Congress of The pharmaceutical Society of Japan 2012) 
すでにFig. 4, 5で示した諸反応を通して生活習慣病を招 くのである $3^{1,4-10)}$. 筆者の千人を超える日本人の時計遺 伝子多型の頻度調查では, CLOCK多型 (rs1801260 のCC 型 4.2\%, rs4864548 のGG型 16\%)，PER多型（rs2304672 のGG型1.0\%) であり, 睡眠時間や生活習慣病との関連 を検討している.

高齢者に見られる睡眠時間の乱れなど，日周リズムの 乱防生活習慣病の原因となるか, 結果に過ざないかは 安易に判定できない，そこで, 厳密な分子生物学の対象で あるショウジョウバエを用いて, リズム乱調が原因であ ると決定した11).すなわち, Perの変異と生活習慣病を促 進する酸化ストレス関連遺伝子を同時に検討したところ, 各々単独でも, 組合せでも寿命を短縮したのである ${ }^{11)}$.

\section{テロメアと生活習慣病}

テロメアは哺乳類細胞の寿命を制御する中心的な役割 を果たしており, 肥満, 糖尿病, 動脈硬化などの老化に 伴う諸疾患の発症に関与している1)。ヒトの体細胞は分 裂毎に短縮し， $5 \mathrm{~kb}$ の限界に達するからである．たとえ ば，高脂肪食による肥満でインスリン抵抗性が増すの で，インスリン分泌を増加するために膵臟の $\beta$ 細胞が増 殖し, 細胞分裂マーカー Ki-67 は高脂肪食群で多くなる (前糖尿病状態の高インスリン血)。しかし, マウス体細 胞の分裂寿命は約10回であるから，やがてテロメア長が 限界に達して老化細胞になる ${ }^{1)}$ 。この老化細胞では形態 が変わり, Ki-67が減少し, 老化関連 $\beta$ ガラクトシダー ゼの活性が増加する ${ }^{12)}$. 膵臟のランゲルハンス島はFig. $9 \mathrm{~A}$ に示すように対照食ではテロメアの尽きた老化細胞 がないがFig. 9Bには, 高脂肪食を11カ月摂取してテロ メアの尽きた老化細胞が発現する $\beta$ ガラクトシダーゼで 青色に染まった細胞が大部分を占めるようになり，イ ンスリン分泌は低下して, 高血糖で糖尿病となってい る ${ }^{12)}$ 。そのテロメア長を実測するとFig. 9C，9Dのよ うに4 カ月時点（青）ではテロメア長は十分に長いが, 11 カ月目には対照食群 (緑)に比へ, 高脂肪食群（赤） では, 対照食に比べてテロメア長が速く短縮している1). この $\beta$ 細胞老化が糖尿病の原因と考えられるようになっ $た^{11)}$. 同様な組織特異的テロメア短縮の例は高血圧患者 の内皮細胞 ${ }^{13)}$, 非アルコール性脂肪肝の肝細胞 ${ }^{14)}$ などが その例である。肝細胞がウイルス性肝炎や非アルコール 性脂肪肝炎 (NASH) で死滅すると, 直ちに代償性に肝 細胞が分裂して行き, 最後に肝細胞の分裂寿命が尽きた 状態が肝硬変である ${ }^{14)}$

時計遺伝子の乱れはテロメア長の短縮として記憶され てゆくが, 多数の生体物質も加齢で老化する。テロメア のDNAは染色体の末端にあって, 遺伝情報をコードし ない二本鎖DNAのG（グアノシン）に富んだ塩基配列 （TTAGGG）が縦列に反復した構造を持っている。リズ
ム乱調による肥満では脂肪細胞や非アルコール性脂肪肝 炎には単球走化性蛋白質 $(\mathrm{MCP})$ が発生してマクロファー ジが集まり, 無菌的慢性炎症反応を起こして活性酸素 （ROS）を発生させる ${ }^{15)}$ ：活性酸素は特にDNAのデオキ シグアノシン $(\mathrm{G})$ を 8 ヒドロキシデオキシグアノシン に酸化する。テロメアの GGG三連塩基は活性酸素に侵 され易い構造であり，細胞分裂の促進なしにテロメア DNA中のGGG配列を酸化してテロメア短縮させ，細胞 寿命を短縮する ${ }^{1)}$. 活性酸素はミトコンドリアDNA変異 を促し, 酸化LDLで動脈硬化を誘発し, 蛋白質の酸化修 飾で生活習慣病を早める。

高齢者の大きな特徵であるエネルギー代謝の低下は心 身の活力を下げ, 生活習慣病の一因となる。 ヒトの線維 芽細胞を 0 歳から 97 歳までの様々な年齢の供与者から得 て調べると年令と共にエネルギー代謝量の基本である呼 吸能（チトクローム酸化酵素活性）の低下と加齢が良く 平行している ${ }^{16)}$. 例えば 97 歳の供与者から得た線維芽細 胞の呼吸量と蛋白質合成能は, 胎児から得たものの僅か 15\%しかなかった16)。このような年齢に依存したミトコ ンドリアの機能はテロメア長で制御されている ${ }^{16)}$.

実際に，高齢者から得たサイトプラスト（核を除去し た細胞質）中の低下したミトコンドリアの活性とミトコ ンドリア合成能は, HeLa細胞 (子宮がん細胞) から作っ た $\rho^{0}$ 細胞（ミトコンドリアを除去した細胞）はテロメ ア長がテロメラーゼで十分に保たれているために, この $\rho^{0}$ 細胞と老化サイトプラストを融合させると, これら 活性が完全に回復されたのである16).

生活習慣病を決兴要因はテロメア長を基本として, これとは独立のミトコンドリアの遺伝子変異蓄積, 細胞 成分の糖化や架橋など多くの指標の老化である.リズム 乱調による高血糖が体蛋白質を糖化し, AGEs（糖化最 終生成物) 蓄積と蛋白質架橋が促進される。アルッハイ マー型認知症のようにテロメア短縮とは無関係なアミロ イド $\beta$ 蛋白質蓄積による細胞死もあるが，アミロイド $\beta$ 蛋白質の脳からの排出は睡眠時間に脳のグリンパ系を介 して行われるので ${ }^{17)}$, 時計遺伝子の関与は明白である。 テロメア長の他に, ミトコンドリア呼吸能, 組織蛋白質 の架橋を始め, 多くの指標が平均約百歳で寿命が尽きる のは, 長い進化の結果と推定されている.

\section{時計遺伝子からテロメアへの情報伝達機構 (略号はFig.の説明を参照)}

運動等の人体活動を駆動しているATPは, 栄養素か ら作られるNADHをミトコンドリアで酸化して得られ るエネルギーでATP合成酵素を分子内回転させて合成 される (Fig. 10) ${ }^{18)}$. 1 日に合成, 分解されるATPの総 量は体重にほほ等しい上に, 脳の自由意志によって骨 格筋や神経の活動が瞬時に数十倍も変動するため, そ 
の代謝は時計遺伝子を含む高度の制御系で調節されて いる ${ }^{18)}$ ，そのエネルギー代謝を制御する主要な因子は $\mathrm{NADH}$ の酸化によって生じるNADと, ATPの消費で生 じるADPとAMPである ${ }^{1,18)}$ ，摂取エネルギーを制限する と NAD と AMP の量が増加し, 動物の健康寿命（健康な 生存期間）を延長することが知られている。適度なエネ ルギー制限は全ての生物に応用できる確実な生活習慣病 予防法であるが，これは生物が飢餓に耐えて種の保存を 計るために進化した機構と考えられている。 その機構は 減食や運動によってNAD/NADH比を高め, 長寿因子 SIRT1（NAD依存性脱アセチラーゼ）が老化機構の諸 蛋白質を脱アセチル化し細胞死を防ぎ，テロメア長と 健康寿命を維持すると推定されている (Fig. 10右下) ${ }^{1)}$. NADが節食（CR）や運動で増加すると長寿因子SIRT1 は直接テロメアに結合して短縮を防ぐことが免疫沈降測 定法で立証されている (Fig. 10左下). SIRT1はNADを
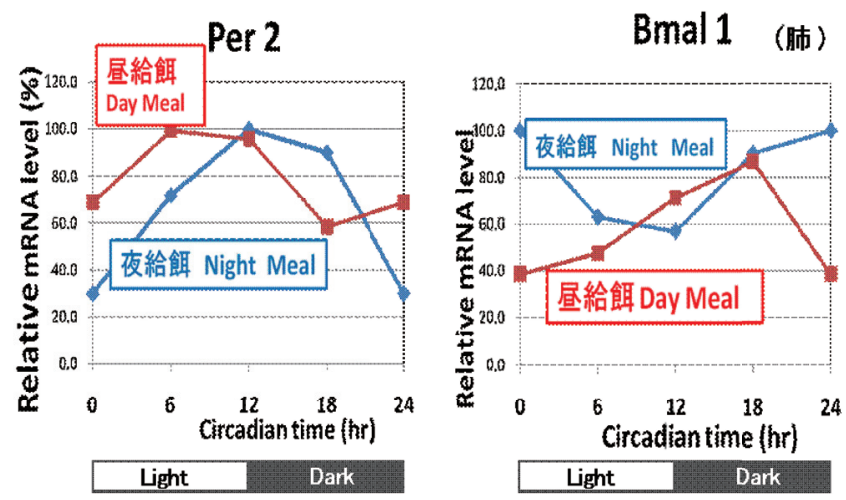

Fig. 7 Effects of meal timing on the circadian rhythm of clock gene expression of Per2 and Bmall.

The amount of mRNA expression Per 2 and Bmall was measured on the lung tissue of mice treated in Fig. 6. (Hiraishi, M., Kagawa, Y. and Horie S. 132th Congress of The pharmaceutical Society of Japan 2012)
アセチル基の受容体として，遺伝子発現のマスター制御 因子（共活性化因子）である PGC-1 $\alpha$ の不活性アセチル 化型のアセチル基 $(\mathrm{Ac})$ をのぞき, その活性を上げる (Fig. 11 中央).

一方, ATPの分解で生じるADPの一部は $2 \mathrm{ADP}=$ $\mathrm{ATP}+\mathrm{AMP}$ のアデニル酸キナーゼ反応でATPを再生す るので, AMPの濃度はADPよりも鋭敏なエネルギー不 足の指標である (Fig. 10右上)。そのためにAMPで活性

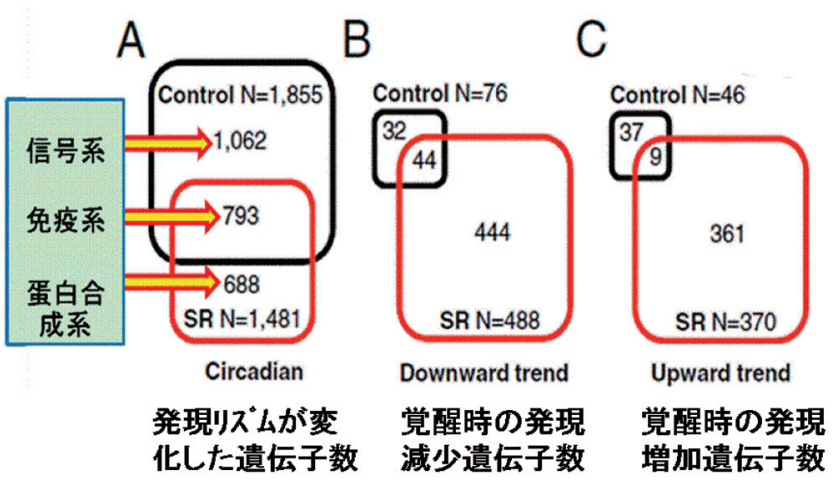

対照群 : 平均8.5 0.11 時間の自由睡眠、睡眠不足群: $5.7 \pm 0.03$ 時間睡眠1㥜間 Nは遺伝子数を示す。被硂者数は26名

Fig. 8 Intersection of genes identified as circadian and time-awake-dependent in control and sleep-restriction (SR) conditions revealed by transcriptome.

(A) Venn diagram of prevalent circadian genes. (B) Venn diagram of genes identified as having a prevalent time-awake upward trend. (C) Venn diagram of genes identified as having a prevalent time-awake downward trend. Transcriptome analysis revealed that 711 genes were up- or down-regulated by insufficient sleep. Insufficient sleep also reduced the number of genes with a circadian expression profile from 1,855 to 1,481 , reduced the circadian amplitude of these genes, and led to an increase in the number of genes that responded to subsequent total sleep deprivation from 122 to 856. Genes affected by insufficient sleep were associated with circadian rhythms (PER1, PER2, PER3, CRY2, CLOCK, NR1D1, NR1D2, RORA, $D E C 1, C S N K 1 E)$. Cited from Ref. 9.
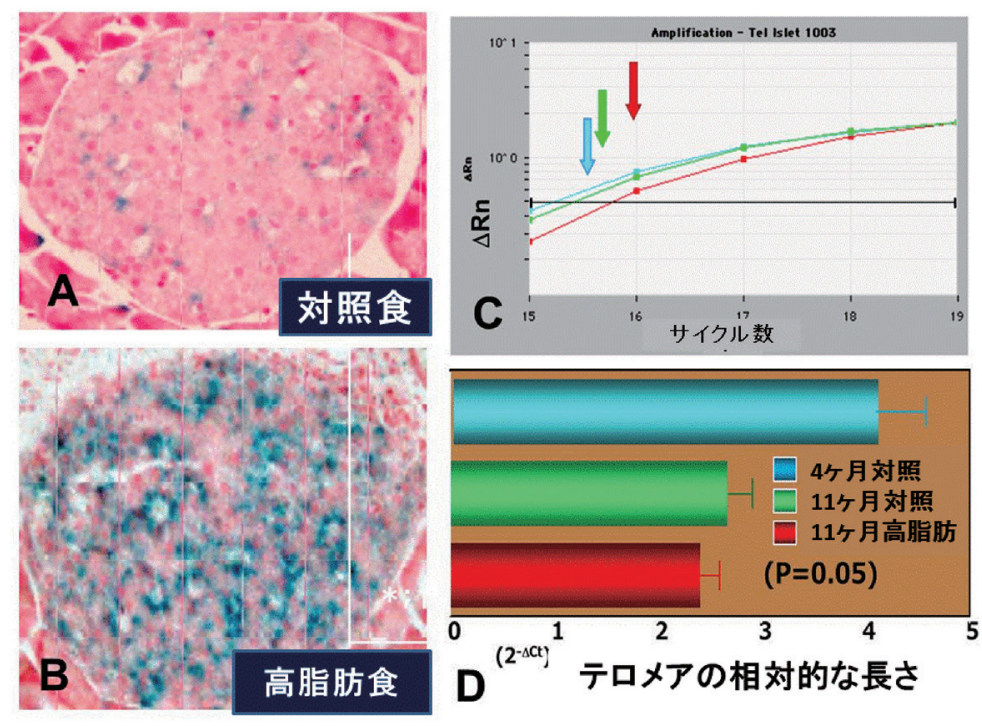

Fig. 9 Detection of $\beta$-cell senescence by $\beta$-galactosidase (panels A and B) and telomere shortening (panels $\mathrm{C}$ and $\mathrm{D}$ ) induced by high-fat diet.

Pancreatic islet of a mouse fed a control diet (A) or a high-fat diet (B) for 11 months. Blue color indicates $\beta$-galactosidase activity. Panel $\mathrm{C}$ : quantitative polymerase chain reaction (PCR) of telomere. Arrows indicate the points at which the threshold line was crossed (blue: 4-month control, green: 11-month control of the mouse in panel A, and red: 11-month highfat diet of the mouse in panel B). Telomere length was determined by real-time kinetic quantitative PCR, as reported by Cawthon. Abbreviations: Cycle, cycle number of PCR; DRn, signal intensity under the specified PCR condition; Ct, threshold cycle value, or the fractional cycle number at which the well's accumulating fluorescence crossed a set threshold that was several standard deviations above baseline fluorescence; $\mathrm{T} / \mathrm{S}$ ratio, the relative ratio of telomere to single-copy gene, approximated by $\left[2^{\mathrm{Ct}(\text { telomeres })} / 2^{\mathrm{Ct}(36 \mathrm{~B} 4)}\right]^{-1}=2^{-\Delta \mathrm{Ct}}$, which is a specific standard primer. (Ref. 1 and 12) 
化されるAMP依存キナーゼは細胞の燃料計と呼ばれる $\mathrm{AMP}$ キナーゼは生体のエネルギー不足を解消するため に, 脂肪酸の $\beta$ 酸化, 糖質の解糖を促進し, 脂肪合成を 停止させる ${ }^{19)}$ ，そのため, いかに良い食事, 運動の夕イ ミングでAMP依存キナーゼの活性を上昇させるかが, メタボリックシンドロームの治療の指標とされる ${ }^{19}$.

節食と運動で増加したAMPはAMP依存キナーゼを活 性化して, 脱アセチル化したPGC-1 $\alpha$ をリン酸化して活 性化する (Fig. 11中央).リン酸基 (P) で活性化された PGC-1 $\alpha$ はマスターキイが多くの扉を開くことができる ように, このマスター制御因子は多くの機能を活性化 する ${ }^{1,20)}$. PGC-1 $\alpha$ はテロメア短縮の大きな原因である 肥満とROSを抑制するがそれはFig. 11下にあるように, 肥満を防ぐミトコンドリアの増殖を促進し, ROS発生の 諸酵素を阻害するからである ${ }^{11}$. 筋肉運動は後述のよう にPGC-1 $\alpha$ を増加させ, 筋肉からイリシンというホルモ ンを分泌させて肥満を防ぐ. PGC-1 $\alpha$ の健康寿命延伸作 用は, 直接的な $\mathrm{PGC}-1 \alpha$ 遺伝子除去マウスを用いて結論 された20)。さらに，SIRT1がテロメアを保護し，中枢時 計の老化を防ぎ, 日周リズムを健全に維持する ${ }^{21)}$ 。また, 視交叉上核内だけでSIRT1を過剩発現させると日周リ ズムは短縮する ${ }^{21}$. 時計遺伝子の乱調で肥満が起こるが, 先述のように肥満は無菌的慢性炎症を誘発し ${ }^{15)}$, 発生す る活性酸素でテロメア短縮を促進し, 脂質を酸化して 老化を促進する ${ }^{15,22)}$. 結論として, PGC-1 $\alpha$ のAMPKと SIRT1による転写後修飾（Fig. 11中央）とPGC-1 $\alpha$ の転 写調節によって, PGC-1 $\alpha$ は時計遺伝子とエネルギー代 謝を総合して ${ }^{20)}$, 活性酸素と肥満を防ぎテロメア短縮を 防止する1).

\section{体力向上と時間栄養学}

体力の向上は生活習慣病の予防の重要な手段であると ともに, 高齢期のサルコペニア, ロコモティブシンド ロームの予防にも重要である. 生活習慣病の平均発症率 が50\%を越える年齢は肥満非運動者 65 歳, 非運動者 72 歳, 普通 80 歳, 持久運動者は 90 歳と大きな差が認めら れる22). 従来, 持久運動の効果は有酸素運動によるミ卜 コンドリアでの脂肪酸消費で肥満が予防されるためと考 えられてきた。しかし, 最近になって, 骨格筋が運動に 伴って, 健康ホルモンであるイリシン（irisin）を分泌し, 脂肪組織に作用して, 脂肪酸酸化を促進し肥満, 糖尿病 を予防することが解明された (Fig. 12 ${ }^{22,23)}$ ，骨格筋の持 久運動は PGC-1 $\alpha$ の発現を増加させる ${ }^{23)}$. PGC-1 $\alpha$ は骨 格筋形質膜中の FNDC5 という骨格筋の発生分化因子を 増加させるが, FNDC5のカルボキシ末端側が切断され てイリシンという骨格筋ホルモンとなる。イリシンは肥 満の核心である白色脂肪組織に作用して, 褐色細胞に似 たベージュ脂肪細胞に変えてATPのエネルギーを熱に
変換する脱共役因子1（UCP1）を発現させて, 減量と血 糖動態を改善する (Fig. 12右下 $)^{23)}$.

競技者のための時間栄養学はカーボローディングや競 技前, 競技中の栄養補給の夕イミングなどが詳しく研究 されているが，一般人の健康のための体力向上にも時間 栄養学が必要である。筋力トレーニングの後には，その 強度が大きいときには, 筋肉の回復のための休息の夕イ ミングが重視される，それに伴って，筋肉増強のための 分枝鎖アミノ酸あるいはそれらに富む乳漿蛋白質の投与 には, 日内の内分泌系自律神経系の活動に合わせる2). 成長ホルモンは, 就寝後90分間に放出されるので, 夕食 時の蛋白質と糖質やカルシウム増加が回復を早め, 筋肉 と骨格の維持, 増強に有効である ${ }^{2)}$. 成長ホルモンは就 眠直後以外にも, 無酸素運動後に大量に分泌されるので, ウオーキング等の有酸素運動の前に筋力トレーニングな どの無酸素運動を併せて行うのが脂肪酸酸化に有効であ る. 蛋白質の損失の激しい患者の回復期に使用されるア ナボリックステロイドは健常な競技者に用いればドーピ ングで問題となる。蛋白質同化作用のある生理的なテス トステロンの運動による分泌増加は少ない。蛋白質の推 奨量はほぼ $1 \mathrm{~g} /$ 体重 $1 \mathrm{~kg}$ であるが, 筋肉増強のために 必要な蛋白質摂取量は 1 日に体重 $1 \mathrm{~kg} \times 2 \mathrm{~g}$ とされる. 分枝鎖アミノ酸と糖質は運動前に摂取するというタイミ ングが有効である ${ }^{24)}$. 蛋白質は消化吸収に時間がかかる ので, トレーニング中では急速に吸収される遊離のアミ ノ酸混合物を摂取するのがよい，不可欠アミノ酸と糖質 の摂取タイミングは重水素標識フェニルアラニンを用い た研究では, トレーニング前30分以内の摂取はレーニ ング後摂取より有意に優れていた ${ }^{24)}$.

\section{食後高血糖の抑制と過激な減量の回避}

摂取速度の速さやグリセミックインデックス (GI) の 高さが血糖值の急激な上昇を招き，それに対応するイン スリン分泌増加で糖が脂質に変えられ肥満を経て糖尿病 となる，同じ食事でも，ゆっくり食べることと, 繊維に 富んだ野菜を先に食べることで，急激な血糖值上昇を防 ぐ (Fig. 13 ${ }^{25)}$. 懷石料理の様に, 時間をかけ, 米飯を最 後に摂取すると良い，同じ糖尿病食でも野菜を先に食べ る教育をした群は， 2 年半後に対照群に較べて，とくに HbAlcの低下が著しく, BMI, LDLなどの改善も有意 に優れていた $\left(\right.$ Fig. 14) ${ }^{25)}$.

最近の日本人の摂取量は米飯よりもパン，それに伴っ て魚類よりも肉類が多くなっている ${ }^{26)}$ ）とくにTPP (環 太平洋戦略的経済連携協定）が妥結すれば小麦, 肉類の 価格が急落して, この傾向に拍車がかかり, 日本人の栄 養に重大な影響を及ぼすと憂慮されている。なぜなら， すでに欧米化した食事を摂る八ワイの日本人では, 白人 の 3 倍も糖尿病の発症率が高いからで, 日本人は白人に 

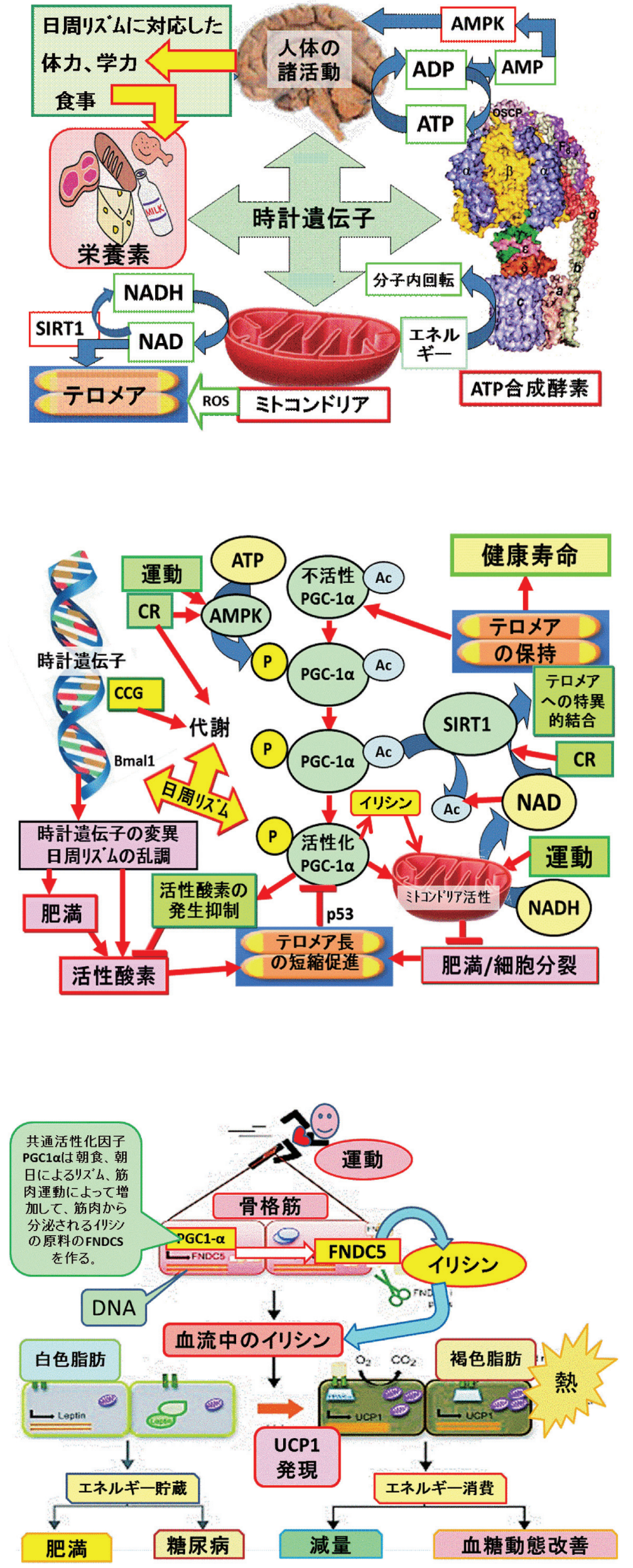

Fig. 10 Central role of clock genes in the regulation of energy metabolism and telomere shortening. Nutrients reduce NAD, while the electron transport system in the mitochondria drives protons to form electrochemical energy, which rotates the central axis of ATP synthase. Clock genes in the suprachiasmatic nucleus (SCN) in the hypothalamus and PGC $-1 \alpha$ in the cells regulate activities driven by ATP. The resulting AMP activates AMPK. The circadian rhythm of metabolism eventually accumulates NAD, a substrate for SIRT1, which maintains telomere length. On the other hand, ROS from mitochondria reduce telomere length. Abbreviations: AMPK, adenosine monophosphate-activated protein kinase; CCG, clockcontrolled genes; ROS, reactive oxygen species; SIRT1 (or NAD-dependent deacetylase sirtuin-1), silent mating type information regulation 2 homolog 1 .

Fig. 11 Relationship between clock gene, telomere, and PGC- $1 \alpha$.

Both caloric restriction (CR) and exercise increase AMP and NAD. PGC $-1 \alpha$ is phosphorylated by AMPK and deacetylated by SIRT1, and it activates the mitochondria. Mitochondrial activation increases NAD and protects telomere length by NAD-dependent deacetylation of SIRT1.

Abbreviations: Ac, acetyl group; AMPK, adenosine monophosphate dependent kinase; ATP, adenosine tri-phosphate; Bmall, Brain and muscle ARNT-like protein 1; CCG, clock-controlled genes; CR, caloric restriction; NAD, nicotinamide adenine dinucleotide; NADH, reduced NAD; P, phosphate group, p53, a tumor inhibitory protein; $\mathrm{PGC}-1 \alpha$, peroxisome proliferator-activated receptor coactivator a; ROS, reactive oxygen species; SIRT1, silent information regulation 2 homolog 1.

Fig. 12 Exercise-induced adipose tissue browning through PGC- $1 \alpha$ and irisin.

Exercise increases the expression levels of PGC-1 $\alpha$ in the muscle. This, in turn, upregulates the expression of FNDC5, a type I membrane protein, which is $\mathrm{C}$-terminally cleaved and secreted as irisin into the circulation. Binding of irisin to an unknown receptor on the surface of adipocytes in white adipose tissue changes their genetic profile. In particular, irisin induces the expression of PPAR- $\alpha$, which is thought to be an intermediate downstream effector that increases the expression of UCP1 (highly expressed in brown adipose tissue and a marker of browning). The browning of white adipose tissue is associated with augmented mitochondrial density and oxygen consumption. Browning is accompanied by an increase in the energy expenditure profile, leading to favorable effects on metabolism such as weight reduction. FNDSC5: Fibronectin type III domain containing 5. UCP1: Uncoupling factor 1. Modified from Ref. 23. 
比してインスリンの分泌量, 分泌速度が約半分と低く (Fig. 15)，エネルギー代謝の遺伝子多型頻度も大きく異 なるからである. GI は白米で 82 と高いが, パンはさらに 高い92である。なぜなら粒食は消化速度が遅いが，パン のような多孔質の構造を持った粉食は消化液が即時に澱 粉を分解して急激な血糖上昇を招くからである.

エネルギー摂取量を夕食で減らし, 朝食で増すと糖尿 病指標は改善する。摂食速度は 1 口25回程度咀嚼して急 激な血糖上昇を抑える。咀嚼回数を自然に増やすには未 精白の穀類など食物絨維を増加する。食物繊維の摂取量 は食事摂取基準では $1000 \mathrm{kcal}$ あたり $10 \mathrm{~g}$ と策定されてい るが27), 現状の $14.2 \mathrm{~g}^{26)}$ は推奨量の約半分だからである.

現在報道されている減量法は月に $10 \mathrm{~kg}$ 瘦せられる等 と減量の速度を競っている。しかし, 脳は血糖だけがエ ネルギー源なので, 血糖の急激な低下によって筋肉や骨 の蛋白質を血糖に変える糖新生反応が起り, 筋萎縮や骨 粗鬆症が起こる。1日の消費エネルギーは日本人平均で $1840 \mathrm{kcal}$, 仮に十分な運動を加えても2000 kcalである が, 脂肪組織 $1 \mathrm{~kg}$ は $7200 \mathrm{kcal}$ なので, $10 \mathrm{~kg}$ 瘦せるには 1 月以上かかるが, 急激な減量に伴う糖新生によって筋 肉は $1 \mathrm{~kg}$ が僅か800 kcalであって, 筋肉が極度に減少す る。その筋肉減少のために, エネルギー消費が減り, 同 じエネルギーを摂取しても肥満が再発する（リバウン ド). 女子栄養大学では, 1 月に $1 \mathrm{~kg}$, すなわち腹囲にし て $1 \mathrm{~cm}$ 程度の減量速度として, 食事の時間栄養学で肥 満を防ぎ，筋肉や骨が減少しないように運動を伴った四 群点数法で栄養バランスを十分にとる。

\section{食事の適正時刻}

日本人の食事摂取基準 ${ }^{27)}$ には, 推奨量や目標量の記載 のみで, 健康に重要な摂取時刻, 食事量の朝昼夕食での 配分, 摂取速度と摂取順序など時間栄養の基準はない。 栄養学的効果は同一献立, 同一量の食事では等しいとい う食事摂取基準の前提は誤りで，同一食事を朝食で摂れ ば夜食の 4 倍の食事誘導性エネルギー発生を心身の起 動に消費し，夜食で摂れば主に脂肪として貯える（Fig. 16).これは, バランスのとれた朝食は時計遺伝子の位 相を合わせて，心身の活動を高め，昼までに体温を約 $1.5^{\circ} \mathrm{C}$ 体温を上昇させるからである。これに対して，朝 食欠食では，時計遺伝子がエネルギー不足を予測して， 心身の活動を下げるので体温上昇は僅かにとどまる ${ }^{2)}$. 朝食は中枢時計遺伝子の位相が朝日でセットされて 2 時 間以内に摂取すると末梢時計遺伝子の位相との同調が良 く, 健康に良い, 夜食では夜間に脂肪酸合成酵素とマロ ニル CoA合成酵素の転写を促進するBmallが増加するの で, 食事のエネルギーの75\%は脂肪に変えられ肥満す るからである ${ }^{2)}$ ，夜食が避けられない場合には，18時頃 に分食を摂り，9時以降は極力摂取量を減らす.
不規則な生活は喫煙による発癌と同様, 苦痛のない数 十年を経て, 糖尿病, 脳卒中や認知症を起こすので直ぐ には効果が判定できない。しかし，不規則に食事制限を 行うと生検で得たヒト脂肪組織の時計遺伝子 (BMAL1, PER1-3,CRY1-2）とCCGsの発現は大きく影響されるこ とが, マイクロアレイ実験で解明され，規則正しい食事 時間が血清脂質, 体温曲線, インスリン抵抗性はじめ客 観的な健康指標を高めることが分子レベルでも確認され た ${ }^{28)}$. このとき, 時計遺伝子の振動する遺伝子とCCGs の発現の位相のずれが肥満を生じる ${ }^{28)}$. 規則的生活に必 要な就眠を助けるには就眠前には橙色で暗い照明にして メラノプシンを介する青色光のメラトニン分泌抑制を避 け，必要があれば就眠 3 時間前にメラトニン $5 \mathrm{mg}$ を内 服する。深夜勤が続くときには，昼間 8 時間は暗くして 完全に睡眠し，外出が避けられない時は黒眼鏡をかけ， 夜間勤務時に明るくして 3 食を摂れば，米国で米国人が 日勤するのと同様，健康を害することはない2).

\section{無理のない時間栄養法による心身の活性化}

生活習慣病を予防し健康寿命（healthspan）を実現す るには, 数十年間の持続した適切な栄養・運動・休養に よって, 時計遺伝子を整え, テロメアの短縮を防げばよ い1,2) 、様々な健康法の中で, 先述の急激な減量を避ける のは当然であるが, 心理的負担の多い減食法もテロメア を短縮させるので逆効果である ${ }^{29)}$ 。つまり，体重を心配 している状態 (preoccupation with weight) では, 白血 球のテロメア長が短縮するのである ${ }^{29)}$ ，とくに誤った減 量の際の不規則な食習慣は, 代謝産物の大きな変動をし ばしば起こし，テロメアを短縮させる ${ }^{30)}$ 。そのため，無 理のない食習慣, 美味しく栄養を摂取できる食事が重要 であり，ヒト白血球テロメアの短縮を遅延させるには GIを下げる食物繊維や抗酸化ビタミンが有効であり ${ }^{31)}$, 逆にテロメアの短縮を促進するリノール酸の過剰や肥満 を促進する多くの条件が解明されている ${ }^{31)}$ 。栄養素や生 理活性物質には有効な摂取時刻があるので, 少量の菓子 なら肥満促進性のBMAL1量の少ない昼間に摂取してよ く, 㛜しい減塩もアルドステロンの少ない夕食で緩和で きる場合がある。成長ホルモンは就寝直後に分泌される ので, 骨粗鬆症予防のカルシウムや筋萎縮予防の高蛋白 質食は夕食に摂ると効果的である。降圧トリペプチドは 血圧のモーニングサージ時に内服し, 抗コレステロール 食品は夕食に摂る. 以上のように時間栄養学を応用して, 無理なく患者が永続できる生活習慣が必要である.

健康寿命の目標はそれによって各人の生涯の目的を達 成するところにある。そのためには単なる寿命延長では なく精神労働に不可欠な知的能力と活力ある体力の増進 が時間栄養学の応用で可能となった。 全国学力テストは 毎年行われ ${ }^{32)}$, 全国体力テストも握力, $50 \mathrm{~m}$ 走など 8 項 


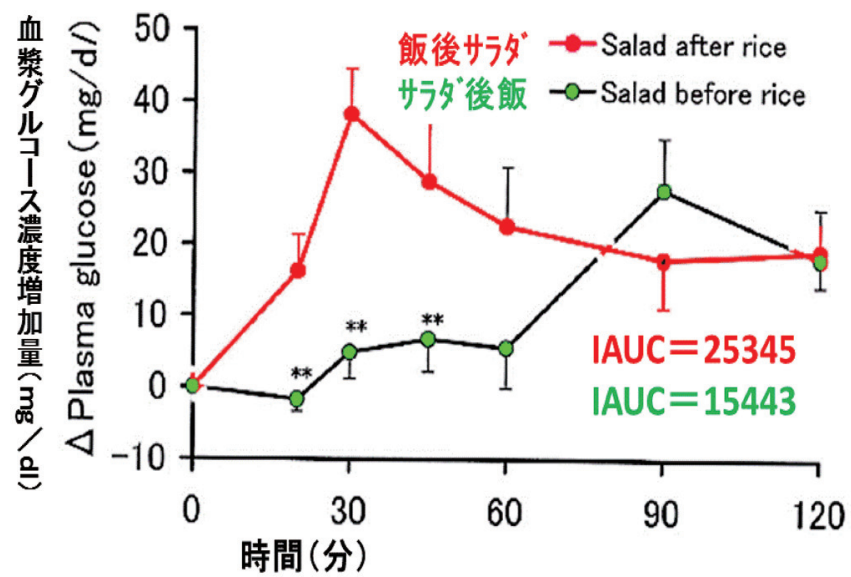

Fig. 13 Time course of plasma glucose at $0,30,60,90$ and 120 min after eating rice before salad (green open circle) or the reverse regimen (red closed circle).

Data are expressed as mean \pm SD. Rice first vs salad first ${ }^{* *} \mathrm{p}<0.01$. Wilcoxon signed rank test for paired data. Cited and modified from Kanemoto I, Inoue H, Moriuchi H, Yamada Y, Imura H, Sato S. Tounyoubyou 53: 96-101, 2010.

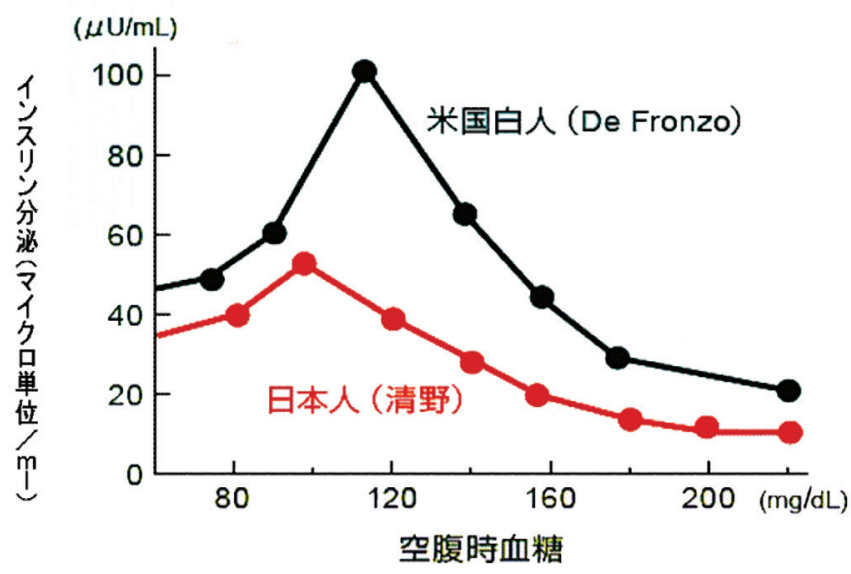

Fig. 15 Ethnic difference of time course of serum insulin after glucose loading between American Caucasians and Japanese.

Cited from Seino Y. Saisin Igaku 50: 639-645, 1995.

目の体力合計点が全国の男女小中学生約 150 万人で調査 されている ${ }^{33)}$. 朝食摂取が学力 (Fig. 17) ${ }^{32)}$, 体力 (Fig.

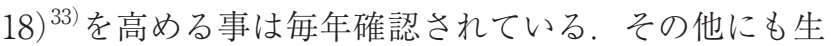
活のリズムが学力, 体力を向上させる重要な要素である ことが報告されている．地域別に見ると学力・体力とも， 朝食摂取頻度の高い秋田, 福井等で高く, それが低い大 阪，沖縄，北海道等で低い，学力も体力もこのように平 行する理由は脳科学の発達で, 時計遺伝子の統合作用等 で脳機能全体を活性化する機構が推定されるようになっ た ${ }^{34)}$. 持久運動は前頭前野の読解力や頭頂葉間溝の数学

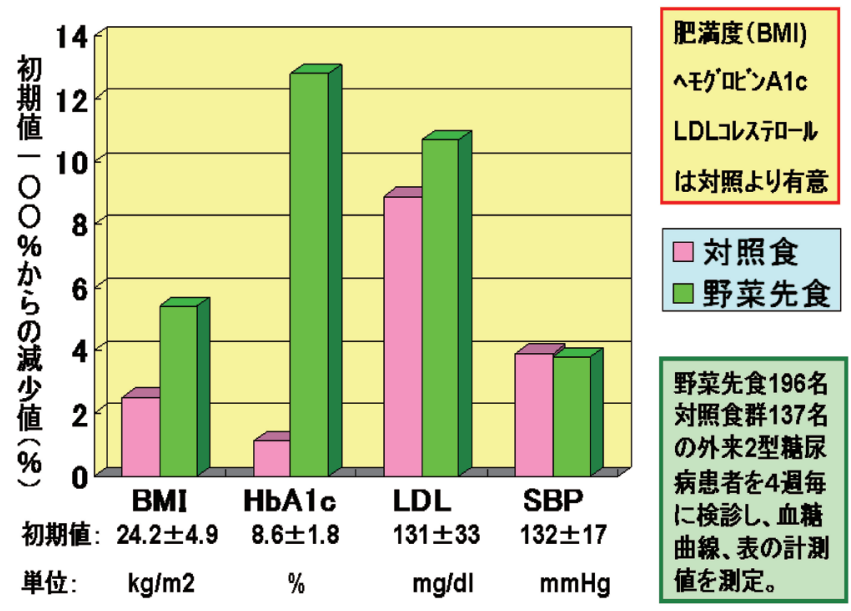

Fig. 14 The effect of eating vegetables before carbohydrates on long term glycemic control.

Clinical parameters of patients in the two study groups: vegetables before carbohydrates (green) vs carbohydrates before vegetables (pink). Educational group taught to eat vegetables first $(\mathrm{n}=196)$ and control group $(\mathrm{n}=137)$ were compared. Data are expressed as mean.

Cited and redrawn from Ref. 25.

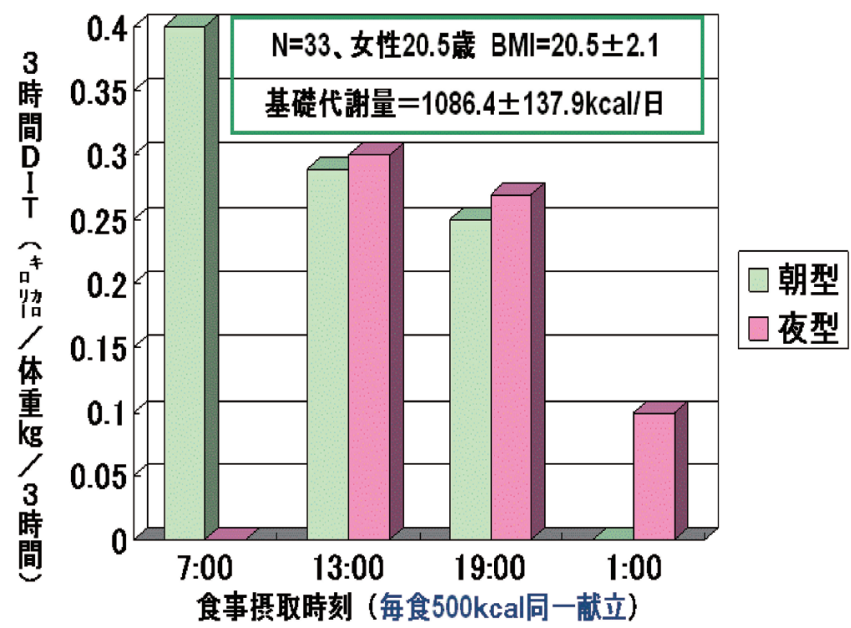

Fig. 16 The influence of eating rhythm on diet-induced thermogenesis in young women.

Subjects (33 females, average age $20.5 \pm 1.2 \mathrm{yr}, \mathrm{BMI}=20.5 \pm$ 2.1) took $500 \mathrm{kcal}$ of the same meal in two patterns: morning type (blue bars) at 7:00, 13:00 and 19:00, and night type (pink bars) at 13:00, 19:00 and 1:00, and then 3hr diet induced thermogenesis were measured. Adapted from Sekino Y, Kashiwa E, Nakamura T. J Jpn Soc Nutr Sci 63: 101-106, 2010.

の能力を高めるだけでなく, 認知症を予防すると報告さ れている ${ }^{34)}$. とくに, 朝食の末梢時計遺伝子への効果は 各栄養素個々の効果ではなく, そのバランスが良いこと が必要であることが, 人工的な栄養素配合食AIN93Mと その各成分の朝食で確認された ${ }^{35)}$ 。事実, 栄養バランス の充実した朝食を摂取すると, 久食者に較べて学力が約 20\%高く, 持久力, 瞬発力ともに全年齢で優れているこ とが報告されている（熊本県学力調查報告 2005 年他). 
朝食の㩑取と学力調育の平均正答率との関保

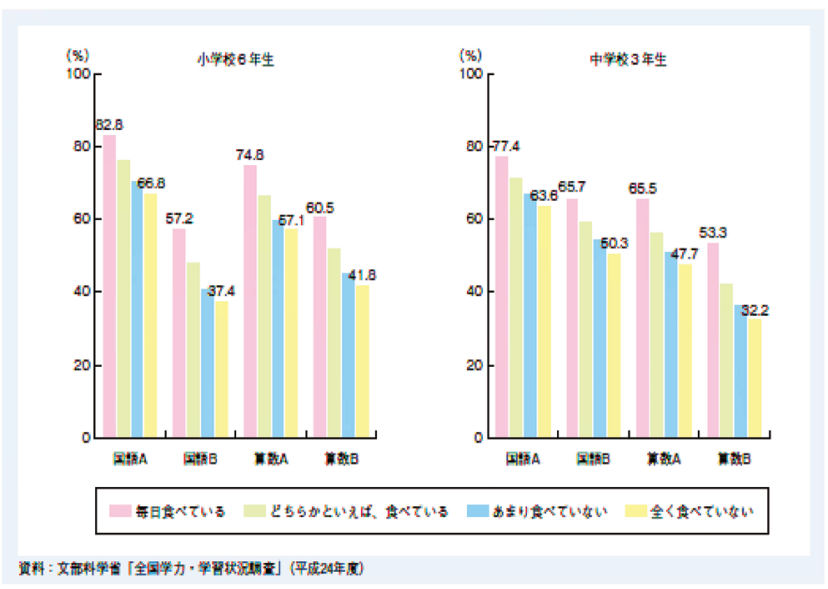

Fig. 17 Average percentages of achievement tests by breakfast skippers and breakfast eaters. Cited from National Academic Research 2012. Ministry of Education, Culture, Sports and Technology, 2012

\section{朝食の摄取と体力合計点との関係}

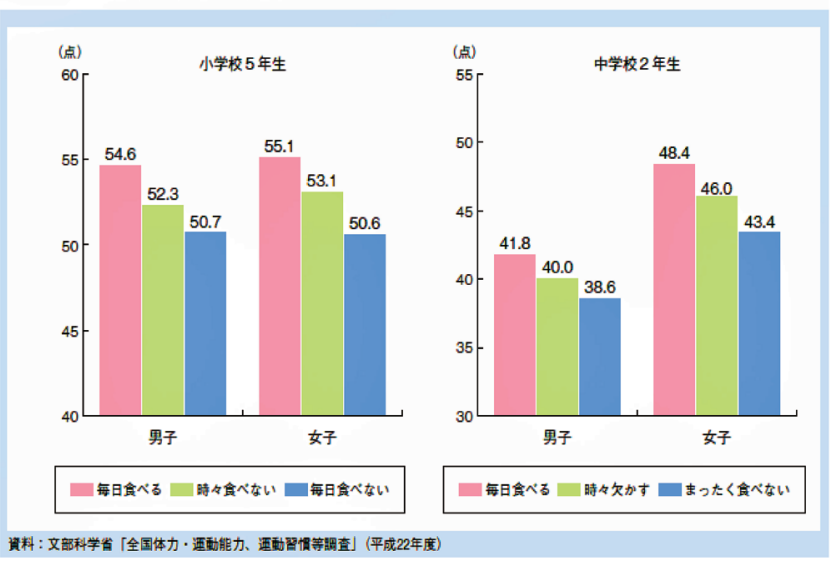

Fig. 18 Average percentages of physical strength tests by breakfast skippers and breakfast eaters. Cited from National Physical Strength Research 2010. Ministry of Education, Culture, Sports and Technology.

\section{おわりに：遺伝要因の生活習慣による克服}

ヒトの時間栄養学では動物実験とは大きく異なり脳の 支配が圧倒的である。そのために健康増進の行動変容を 促す。もしも健康寿命が生活習慣病の終点である心疾患, 癌，糖尿病などのリスク遺伝子で主に決定されているの ならば, 節制の効果はそしい。しかし, 全ゲノム関連研究 の結果では, リスク遺伝子数は 85 歳以上の長寿者で 26.8 \pm 0.11 個, 対照者でもほぼ同数の $26.8 \pm 0.10$ 個であった 36 . この結果から,リスク遺伝子の発現を遅延させる節制が 重視されるのである。厚生労働省の「健康づくりのため の身体活動指針」37)では今より10分多く身体活動を奨励 するが，非運動の人では僅か10分間の運動でも生活習慣 病予防の鍵である PGC-1 $\alpha$ が増加するのである ${ }^{38)}$. 動物
でもヒトでも時計遺伝子の多型が生活習慣病のリスクと なる6,10,39)．しかし，CLOCKやPER多型があっても，学 生や市民で規則正しい生活を守り BMIを 22 に合わせる ならば，血糖，血清脂質は野生型と有意な差は無かった （香川2014）。このように，ヒトの脳は自らの意志で快楽 を求め，また節制をして，日周リズム，栄養，運動を変 化させ，時計遺伝子を介してテロメアを維持し健康寿命 を左右できるのである $(\text { Fig. 1 })^{1)}$.

\section{文献}

1) Kagawa Y. From clock genes to telomeres in the regulation of the healthspan. Nutr Rev 70: 459-471, 2012.

2）香川靖雄編, 時間栄養学, 女子栄養大学出版部, 東京, pp.1-158, 2009.

3) Scheer FA, Hilton MF, Mantzoros CS, Shea SA. Adverse metabolic and cardiovascular consequences of circadian misalignment. Proc Natl Acad Sci USA 106: 4453-4458, 2009.

4) Kripke DF, Garfinkel L, Wingard DL, Klauber MR, Marler MR. Mortality associated with sleep duration and insomnia. Arch Gen Psychiatry 59: 131-136, 2002.

5) Prather AA, Puterman E, Lin J, O'Donovan A, Krauss J, Tomiyama AJ, Epel ES, Blackburn EH. Shorter leukocyte telomere length in midlife women with poor sleep quality. J. Aging Res 2011: 721390, 2011.

6) Woon PY, Kaisaki PJ, Bragança J, Bihoreau MT, Levy JC, Farrall M, Gauguier D. Aryl hydrocarbon receptor nuclear translocator-like (BMAL1) is associated with susceptibility to hypertension and type 2 diabetes. Proc Natl Acad Sci USA 104: 14412-14417, 2007.

7) Luyster FS, Strollo PJ Jr, Zee PC, Walsh JK; Boards of Directors of the American Academy of Sleep Medicine and the Sleep Research Society. Sleep: a health imperative. Sleep 35: 727-734, 2012.

8) Shilsky JD, Hartman TJ, Kris-Etherton PM, Rogers CJ, Sharkey NA, Nickols-Richardson SM. Partial sleep deprivation and energy balance in adults: an emerging issue for consideration by dietetics practitioners. $J$ Acad Nutr Diet 112: 1785-1797, 2012.

9) Möller-Levet1 CS, Archer1 SN, Bucca G, Laing EE, Slak A, Kabiljo R, Lo JC, Santhi N, von Schantz M, Smith CP, Dijk DJ. Effects of insufficient sleep on circadian rhythmicity and expression amplitude of the human blood transcriptome. Proc Natl Acad Sci USA 110: E1132-E1141, 2013.

10) Kondratov RV, Kondratova AA, Gorbacheva VY, Vykhovanets OV, Antoch MP. Early aging and age-related pathologies in mice deficient in BMAL1, the core component of the circadian clock. Genes Dev 20: 1868-1873, 2006.

11) Krishnan N, Rakshit K, Chow ES, Wentzell JS, Kretzschmar D, Giebultowicz JM. Loss of circadian clock accelerates aging in neurodegeneration-prone mutants. Neurobiol Dis 45: 1129-1135, 2012.

12) Sone $H$ and Kagawa $Y$. Pancreatic beta-cell senescence 
contributes to the pathogenesis of Type 2 diabetes in high-fat diet-induced diabetic mice. Diabetologia 48: 58-67, 2005.

13) Fitzpatrick AL, Kronmal RA, Gardner JP, Psaty BM, Jenny NS, Tracy RP, Walston J, Kimura M, Aviv A. Leukocyte telomere length and cardiovascular disease in the cardiovascular health study. Am J Epidemiol 165: 14-21, 2007.

14) Nakajima T, Moriguchi M, Katagishi T, Sekoguchi S, Nishikawa T, Takashima H, Kimura H, Minami M, Itoh Y, Kagawa K, Tani Y, Okanoue T. Premature telomere shortening and impaired regenerative response in hepatocytes of individuals with NAFLD. Liver Int 26: 23-31, 2006.

15) Wellen KE, Hotamisligil GS. Obesity-induced inflammatory changes in adipose tissue. J Clin Invest 112: 1785-1788, 2003.

16) Hayashi J-I, Ohta S, Kagawa Y, Kondo H, Kaneda H, Yonekawa H, Takai D, Miyabayashi S. Nuclear but not mitochondrial genome involvement in human agerelated mitochondrial dysfunction. Functional integrity of mitochondrial DNA from aged subjects. $J$ Biol Chem 269: 6878-6883, 1994

17) Iliff JJ, Wang M, Liao Y, Plogg BA, Peng W, Gundersen GA, Benveniste H, Vates GE, Deane R, Goldman SA, Nagelhus EA, Nedergaard M. A paravascular pathway facilitates CSF flow through the brain parenchyma and the clearance of interstitial solutes, including amyloid $\beta$. Sci Transl Med 4: 147ra111, 2012.

18) Kagawa Y. ATP synthase: from single molecule to human bioenergetics. Proc Jpn Acad Ser B Phys Biol Sci 86: 667-693, 2010.

19) Violleta B, Mouniera R, Leclerc J, Yazigi A, Foretz M, Andreelli F. Targeting AMP-activated protein kinase as a novel therapeutic approach for the treatment of metabolic disorders. Diabetes and Metabolism 33: 395402, 2007.

20) Liu C, Li S, Liu T, Borjigin J, Lin JD. Transcriptional coactivator PGC-1alpha integrates the mammalian clock and energy metabolism. Nature 447: 477-481, 2007.

21) Belden WJ, Dunlap JC. Aging well with a little wine and a good clock. Cell 153: 1421-1422, 2013.

22) Handschin C1, Spiegelman BM. The role of exercise and PGClalpha in inflammation and chronic disease. Nature 454: 463-469, 2008.

23) Castillo-Quan, JI. From white to brown fat through the PGC-1 $\alpha$-dependent myokine irisin: implications for diabetes and obesity. Dis Model Mech 5: 293-295, 2012.

24) Tipton KD1, Rasmussen BB, Miller SL, Wolf SE, Owens-Stovall SK, Petrini BE, Wolfe RR. Timing of amino acid-carbohydrate ingestion alters anabolic response of muscle to resistance exercise. Am J Physiol Endocrinol Metab 281: E197-E206, 2001.

25) Imai S, Fukui M, Kajiyama S. Effect of eating vegetables before carbohydrates on glucose excursions in patients with type 2 diabetes. $J$ Clin Biochem Nutr 54: 7-11, 2014.

26）厚生労働省. 平成24年国民健康 ·栄養調査速報值（イン ターネット), 2014.

27）厚生労働省. 日本人の食事摂取基準 2015年版速報值（イ ンターネット), 2014.

28) Farshchi HR, Taylor MA, Macdonald IA. Beneficial metabolic effects of regular meal frequency on dietary thermogenesis, insulin sensitivity, and fasting lipid profiles in healthy obese women. Am J Clin Nutr 81: 16-24, 2005.

29) Kiefer A, Lin J, Blackburn E, Epel E. Dietary restraint and telomere length in pre- and postmenopausal women. Psychosom Med 70: 845-849, 2008.

30) Epel E. Psychological and metabolic Stress: a recipe for accelerated cellular aging? Hormone 8: 7-22, 2009.

31) Cassidy A, De Vivo I, Liu Y, Han J, Prescott J, Hunter DJ, Rimm EB. Associations between diet, lifestyle factors, and telomere length in women. Am J Clin Nutr 91: 1273-1280, 2010.

32）文部科学省.「全国学力・学習状況調査 平成24年度」, 2012.

33）文部科学省.「全国体力・運動能力, 運動習慣等調査 平 成22年度」, 2010.

34) Hillman CH1, Erickson KI, Kramer AF. Be smart, exercise your heart: exercise effects on brain and cognition. Nat Rev Neurosci 9: 58-65, 2008.

35) Hirao A, Tahara Y, Kimura I, Shibata S. A balanced diet is necessary for proper entrainment signals of the mouse liver clock. PLoS One 4: e6909, 2009.

36) Beekman M, Nederstigt C, Suchiman HE, Kremer D, van der Breggen R, Lakenberg N, Alemayehu WG, de Craen AJ, Westendorp RG, Boomsma DI, de Geus EJ, Houwing-Duistermaat JJ, Heijmans BT, Slagboom PE. Genome-wide association study (GWAS) -identified disease risk alleles do not compromise human longevity. Proc Natl Acad Sci US A 107: 18046-18049, 2010.

37）厚生労働省. 健康づくりのための身体活動指針（アク ティブガイド), 2013

38) Stepto NK, Benziane B, Wadley GD, Chibalin AV, Canny BJ, Eynon N, McConell GK. Short-term intensified cycle training alters acute and chronic responses of PGC1 $\alpha$ and Cytochrome C oxidase IV to exercise in human skeletal muscle. PLoS One 7: e53080, 2012.

39) Sookoian S, Gemma C, Gianotti F, Burgueño A, Castaño G, Pirola CJ. Genetic variants of Clock transcription factor are associated with individual susceptibility to obesity. Am J Clin Nutr 87: 1606-1615, 2008. 